\title{
Disordered function of mononuclear phagocytes in malignant disease
}

\author{
RJ SOKOL, G HUDSON \\ From the University Department of Haematology, Royal Hallamshire Hospital, Sheffield, S10 2JF
}

In previous reports there have been scattered references to possible disorders in function of macrophages in malignant disease. For example, a decrease in macrophage numbers was reported in skin window exudates of patients with Hodgkin's granuloma, ${ }^{1}$ while the foreign body inflammatory response within a variety of transplantable tumours in subcutaneous sites in rodents was found to be minimal. ${ }^{2}$ More recently there have been reports relating to mononuclear phagocyte functions in cancer. ${ }^{3-6}$ This review considers the evidence for macrophage dysfunction in neoplastic disease both in relation to our own studies and to other recent investigations. The disorders are considered in relation to: (i) cell maturation; (ii) migration and chemotaxis; (iii) phagocytosis, cytotoxicity and related phenomena; (iv) lysozyme secretion; and ( $v$ ) macrophages within malignant tumours.

\section{DISORDERS OF MATURATION}

Macrophage changes in malignant lymphoma were observed in our laboratory during a series of investigations of the cutaneous inflammatory response. ${ }^{7-9}$ Observations were made on skin window preparations in 20 patients with Hodgkin's disease (all untreated) and 20 with non-Hodgkin's lymphoma (13 untreated), and compared with the findings in 29 normal subjects.

On scanning electron microscopy, the surface appearances of macrophages were generally more varied in lymphoma. Whereas in normal subjects over $90 \%$ of the macrophages in two-day skin window preparations showed close-packed surface microvilli, less than $50 \%$ of macrophages showed these appearances in similar preparations from lymphoma patients; ridged and ruffled forms were more frequent and on statistical analysis, the difference was highly significant (Table 1). These findings were independent of treatment and no patient was suffering from an infection at the time of study.

Accepted for publication 8 November 1982
The microvillous appearances were typical of ${ }_{\omega}^{\infty}$ mature macrophages, ${ }^{10}$ the proportion of cells with $\dot{\omega}$ this form significantly increasing in normal subjects $\vec{\sigma}$ between the first and second day. The ridged and 0 ruffled appearances, which were similar to those seen in blood monocytes ${ }^{11}$ and in monocytes after 3 only a few hours in culture,${ }^{10}$ reflected immaturity.

The increased percentages of such forms in lym- $\stackrel{\circ}{د}$ phoma patients can be interpreted as a failure in $\vec{\theta}$ maturation of the mononuclear phagocytic cells $\underset{\omega}{\infty}$ migrating from the blood to the site of the inflammation. ${ }^{12} 13$

This evidence of a maturational defect in patients with malignant lymphoma has been paralleled with observations on the proportion of blood monocytes $\stackrel{\circ}{\mathbb{Q}}$ which mature into macrophages after a week in cul- $\stackrel{2}{\Rightarrow}$ ture. ${ }^{14-22}$ In these studies, the cells have been assessed by their adhesiveness, cell identity being confirmed by a variety of other standard techniques. Maturation was reported to be depressed in patients with squamous cell carcinoma of the lung, ${ }^{14}$ malignant melanoma ${ }^{15-17}$ and renal cell carcinoma. ${ }^{18} \mathrm{~A}$ : similar defect was found in patients with breast 3 cancer using a dye elution technique. ${ }^{19}$ The applica- $\delta$ bility of these findings to the in vivo situation is strongly suggested by the fact that depression of 0 maturation could be correlated with overall tumour burden $^{20}$ and equated with poor prognosis. ${ }^{21} 22$

Table 1 Surface features of skin window macrophages in $\mathrm{C}$ lymphoma

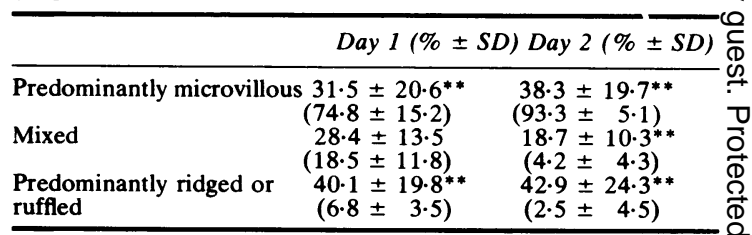

Corresponding normal values are shown in parentheses.

**Indicates a highly significant difference from normal $(p<0.01)$. 


\section{DISORDERS OF MIGRATION AND CHEMOTAXIS}

In our skin window studies in malignant lymphoma, ${ }^{89}$ there was also a highly significant depression in overall cellularity in both one-day and twoday preparations (Table 2). This was again independent of treatment and affected both Hodgkin's and non-Hodgkin's lymphoma patients. These findings may be interpreted as reflecting a defect in mononuclear phagocyte migration. This would also explain earlier reports of a depression in skin window cellularity in both Hodgkin's disease ${ }^{1}$ and non-Hodgkin's lymphoma. ${ }^{23}$ A normal exudate has been reported in Hodgkin's disease ${ }^{23}$ but observations were only made over the first $20 \mathrm{~h}$.

In patients with disseminated carcinomas, significantly fewer macrophages have been found in skin window preparations and in skin chambers. ${ }^{24-29}$ Although these tumours had arisen from a variety of primary sites and the patients had widely differing clinical and therapeutic histories, the overall picture of reduced migration is convincing. In a recent study ${ }^{29}$ in which all the patients were untreated, the changes were more marked with advanced disease and extensive nodal involvement, and the depression of the macrophage response could be reversed with immunotherapy or plasma exchange. However, in patients with localised carcinomas, there was an increased monocyte mobilisation which returned to normal when the tumour was resected. ${ }^{26-29}$

The migration of macrophages into inflammatory exudates has also been studied in rats with subcutaneous transplants of chemically-induced tumours $^{30}$ or with intramuscular transplants of syngeneic sarcomas. ${ }^{31}$ The number of macrophages elicited in a peritoneal exudate in response to an inflammatory stimulus was decreased. The decrease was related to progressive tumour growth ${ }^{31}$ and in advanced disease, there was a complete block in the rats' capacity to mobilise these cells. ${ }^{30}$

Depression of the chemotactic responses of blood monocytes in vitro has also been reported in malignant disease by numerous investigators. In these studies, the monocyte response to standard chemotactic factors was examined in Boyden chambers. The malignancies included melanoma, carcinoma, lymphoma, sarcoma, and multiple myeloma and in all cases, a significant proportion of patients

Table 2 Cellularity scores of skin window exudates in lymphoma

\begin{tabular}{ll}
\hline Day 1 (Mean \pm SD) & Day $2($ Mean \pm SD) \\
\hline $1.67 \pm 0.62^{* *}$ & $1 \cdot 73 \pm 0.64^{* *}$ \\
$(2 \cdot 10 \pm 0.59)$ & $(2 \cdot 21 \pm 0.65)$ \\
\hline
\end{tabular}

See footnotes to Table 1 . showed a depressed response. ${ }^{32-45}$ This was related to the severity of the disease and the prognosis, ${ }^{41446-48}$ and was partially reversed by treatment or immunotherapy. 3536424449

\section{DISORDERS IN PHAGOCYTOSIS, CYTOTOXICITY AND RELATED PHENOMENA}

Reports relating to the phagocytic and cytotoxic activities of mononuclear phagocytes in malignant disease $e^{2039404250-73}$ have often seemed conflicting. These functions have sometimes been enhanced but in other situations have been normal or depressed. It may therefore be helpful at this point to note that differences may be reconciled if the mononuclear phagocyte response is seen as reflecting a balance between stimulatory and inhibitory influences in the subject concerned. The balance might be expected to be different at different stages of the disease. Infections can also disturb these functions ${ }^{69}$ and intercurrent infections, though not specifically mentioned in the literature, may sometimes have complicated the picture.

Phagocytic activity has been studied in vitro by measuring the uptake of micro-organisms, erythrocytes or latex particles. Increased phagocytic activity has been found in blood monocytes and monocytederived macrophages in untreated patients with Hodgkin's disease ${ }^{50}$ and miscellaneous carcinomas. ${ }^{5152}$ However decreased phagocytic activity has also been reported in Hodgkin's disease, ,3-55 $^{53-5}$ notably in stages III and IV. ${ }^{53} 54$ In skin window macrophages of lymphoma patients, depressed phagocytosis was independent of treatment. ${ }^{56}$

Blood mononuclear cells showed an increased phagocytosis-related reduction of NBT (nitro blue tetrazolium) in micrometastatic melanoma, ${ }^{2057}$ whereas there was an impairment of NBT reduction in disseminated melanoma. ${ }^{2057}$ Such observations might suggest that monocytes from patients with minimal disease are in some way activated, in contrast to their functional impairment in more advanced disease. However, the picture is by no means clear-cut. Increased chemiluminescence on phagocytosis was noted in the monocytes of patients with lymphomas, but no difference was found in patients with solid tumours.58 Similarly, differing effects have emerged from studies of whole-body reticuloendothelial activity. As judged by the clearance of labelled aggregated albumin or lipid test emulsion from the blood, increased activity was found in patients with carcinomas and lymphomas, most of whom were untreated..$^{59-61}$ In studies in mice, bearing subcutaneously inoculated Lewis lung carcinoma, clearance of carbon was initially depressed during tumour growth, then became enhanced, but progressively decreased in the later stages. ${ }^{62}$ 
In studies of the activity of mononuclear phagocytes against target cells and micro-organisms, varying effects have again been noted. Enhanced haemolytic activity was reported in blood mononuclear cells in malignant melanoma ${ }^{63}$ but was similar to normal in a series of lymphoma patients. ${ }^{64}$ However, impaired cytotoxicity to target cells was present in other patients with untreated Hodgkin's disease, ${ }^{65}$ colon carcinomas ${ }^{66}$ and other malignancies. ${ }^{67} \mathrm{Simi}-$ larly, bactericidal activity of blood monocytes was depressed in untreated patients with lymphoma $^{395468}$ but in other studies, such patients showed enhanced staphylocidal and candidacidal activity, ${ }^{69}$ a modest depression being noted in successfully treated patients. ${ }^{70}$ Bacterial killing was normal in patients with mycosis fungoides. ${ }^{40}$

Fc receptor expression on mononuclear phagocytes also appears to be affected in different degrees. This has been investigated by erythrocyte rosetting techniques. In one series of patients with untreated carcinomas, blood monocytes showed increased $\mathrm{Fc}$ receptor expression, ${ }^{71}$ but no change was noted in another series..$^{42}$ Increased numbers of $\mathrm{Fc}$ and $\mathrm{C} 3$ receptor sites were displayed by monocytes of cancer patients after immunotherapy. ${ }^{72}$ While Fc receptor expression was increased in the blood monocytes of patients with lung cancer, it was locally decreased on the pulmonary alveolar macrophages. ${ }^{73}$

Although no consistent pattern emerges from the above observations on phagocytic and cytotoxic activities of mononuclear phagocytes in malignant disease, they would give general support to a working hypothesis that the frequently reported enhancements are mainly a host reaction which would be expected to predominate where there is a smaller tumour load and a less aggressive condition. Conversely, decreased function would result from activity of the tumour and would be expected to be more marked in advanced disease and in the vicinity of the growth.

\section{DISORDERS OF LYSOZYME SECRETION}

There is some evidence that the synthesis and release of lysozyme by mononuclear phagocytes are disturbed in malignant disease. Raised serum lysozyme activities have frequently been reported in patients with neoplastic disorders, but in a large series of untreated patients with malignant melanoma, hypernephroma and breast carcinoma (who were free from infections and unrelated gross pathology), raised activities were confined to the ones with localised disease, ${ }^{74}$ although they were also found as a transient postoperative phenomenon in recurrent or metastatic colorectal cancer. ${ }^{75}$ Plasma activities were raised in a series of patients with untreated Hodgkin's disease; the lysozyme $\underline{\vec{\sigma}}$ activities reflected the tumour mass and activity since they could be correlated with clinical stage and $\stackrel{\vec{\rho}}{\rightarrow}$ symptoms, and decreased with cytotoxic treat- $\bar{C}$ ment. ${ }^{76}$ In rats with intramuscular implants of a chemically induced fibrosarcoma, the raised serum $\frac{\bar{N}}{7}$ lysozyme activity reflected the macrophage content $\stackrel{\mathbb{}}{\AA}$ of the tumour and draining lymph nodes. ${ }^{77}$ In lymph node macrophages themselves, marked differences were found in the immunohistochemical reaction for $?$ lysozyme in untreated Hodgkin's disease. ${ }^{87} \overrightarrow{\vec{\omega}}$ Enhanced lysozyme secretory activity was associ- $\stackrel{\omega}{\sigma}$ ated with more favourable clinical and his- $\vec{?}$ topathological features, whereas depressed activity $\omega$ was present in patients with poorer prognosis. ${ }^{79}$

From the above observations, it would appear $\dot{\omega}$ that lysozyme secretion may be affected by host and $\vec{\sigma}$ tumour influences in the same way as the other func-? tions discussed.

\section{DISORDERS OF MACROPHAGES WITHIN MALIGNANT TUMOURS}

There is abundant evidence for the presence of mac- $\vec{\varphi}$ rophages within malignant tumours. Observations in $\underset{\omega}{\infty}$ experimental murine carcinomas and sarcomas indicated that Fc receptor-bearing cells were present in the tumours and that many if not all were macrophages of host origin. ${ }^{8081}$ The question arises as to what effect these macrophages exert on the tumour $\frac{\circ}{\Phi}$ and why it is not eliminated.

In hamsters with transplantable lymphomas, macrophages present in non-metastasising tumours were of large size and on electron microscopy could be seen to be engaged in phagocytosis and disruption of malignant cells, whereas macrophages in metastasis-융 ing tumours were small and without phagosomes. ${ }^{82}$ : In transplantable sarcomas in rats, both metastasising and non-metastasising in character, macrophage $\delta$ precursors were present which were apparently $₹$ inhibited from proliferating by the presence of the 0 neoplastic cells but did so when separated from them in vitro. ${ }^{83}$ Similarly macrophage monolayers derived from certain solid tumours in rats were cytotoxic to tumour cells in vitro, although apparently $\overparen{S}$ not in vivo. ${ }^{84}$

Evidence that the macrophages found within tumours are functionally depressed was also pro- 0 vided by the report that mice carrying sarcomas or mastocytomas in the footpad were incapable of $\frac{0}{\Phi}$ eliminating Listeria monocytogenes from the $\stackrel{\oplus}{\oplus}$ tumour, although the organism was efficiently elimi- 0 nated from other sites. ${ }^{85}$ The establishment and growth of the tumour may in fact depend on the $\mathbb{\mathbb { D }}$ subversion of mononuclear phagocyte function: $\frac{\vec{D}}{\mathrm{D}}$ macrophages isolated from progressive lesions after $\frac{\varrho}{\sigma}$ the inoculation of Moloney sarcoma cells in mice 
were less cytotoxic to target cells than those from regressing lesions. ${ }^{86}$ However, such subversion is potentially reversible and regression of subcutaneous tumour nodules in patients with malignant melanoma or carcinoma of the breast has been observed after injection of a reticuloendothelial activator (Glucan) directly into the lesion; the regression was associated with the finding of large macrophages with foamy cytoplasm. ${ }^{87}$

The number of macrophages within the tumour may also be important in relation to its progression. The possible prognostic significance of the degree of lymphoreticular infiltration of human tumours was pointed out in a review of the earlier literature. ${ }^{88}$ Similarly in a series of autochthonous and early passaged murine sarcomas, the tumours with the lowest proportion of macrophages (identified by surface markers and phagocytic property) appeared earlier and killed the host more rapidly. ${ }^{89}$ Both human and animal studies have consistently found that fewer macrophages are present in metastasising tumours $^{31}$ 90-92 and increased potential for metastasis was produced in transplanted murine fibrosarcomas when the inoculum was artificially depleted of macrophages. ${ }^{93}$

Thus, it would appear that the natural history of a tumour, including its ability to metastasise, may be influenced both by the number of macrophages gaining access to the tumour mass, and by the extent to which their functional activities have been subverted. However, other factors including the release of soluble tumour-specific antigens may also be implicated in metastatic spread. ${ }^{94}$

\section{Possible mechanisms of disturbed function}

The disorders of macrophage function considered above may be largely determined by host and tumour factors of a chemical or physicochemical nature.

Raised concentrations of chemotactic factor inactivator, a naturally occurring regulator of the inflammatory reaction, were demonstrated in the serum of patients with Hodgkin's disease. ${ }^{95}$ Similarly, a factor, which is present in the plasma of normal individuals and which inhibits migration of macrophages, was shown to be significantly raised in $70 \%$ of patients with untreated solid tissue neoplasms and lymphomas: ${ }^{96}$ this factor had a relative molecular mass (rmm) of over 600000 and was possibly an $\alpha_{2}$ macroglobin. An inhibitor of macrophage accumulation in vivo and of chemotaxis in vitro was described in the supernatants of murine tumour cells; ${ }^{97}$ it had a low rmm (6000-10 000) and was heat-stable. This macrophage chemotactic inhibitor (MCI) enhanced growth of several transplanted murine tumours in vivo, possibly by retarding the localisation of macrophages in the developing tumours. ${ }^{98}$ Decreased production of $\mathrm{MCI}$ was found in an attenuated strain of murine lymphoma, which behaved like a virulent strain when $\mathrm{MCI}$ was concurrently injected..$^{99}$ Tumour extracts and sera from mice with Lewis lung carcinoma have similarly been shown to depress macrophage migration in vitro. ${ }^{62}$ In other studies in which chemotaxis of macrophages in vitro was inhibited by culture supernatants, the inhibitory substance apparently bound onto the macrophage cell surface. ${ }^{100}$ The presence of a growing tumour (following inoculation of transplantable tumour cells in rodents) also interfered with macrophage accumulation in vivo but required a relatively large threshold number of tumour cells. ${ }^{101-103}$

Culture supernatants from murine tumour cells (as well as from normal thymus and lymph node cells) have similarly been found to suppress macrophage spreading in culture ${ }^{104}$ apparently by inhibiting the fixation of bradykinin to macrophage membranes. ${ }^{105} \mathrm{~A}$ factor of low rmm obtained from various transplantable mouse tumours (both spontaneous and induced) inhibited the ability of cultured macrophages to attach to the substratum and spread. ${ }^{106}$

There is evidence that similar factors may be responsible for the disordered phagocytosis and cytotoxicity. A factor obtained from the supernatants of human colon carcinoma cells inhibited phagocytosis in rabbit peritoneal macrophages ${ }^{107}$ and likewise, an antiphagocytic action was shown by supernatants of mouse sarcoma cells, a heat-stable factor with an rmm of over 10000 being involved. ${ }^{108}$ A factor with an rmm of less than 12000 was liberated into the circulation of mice in the early stages after tumour cell injection and resulted in a shortlived but severe impairment of antibacterial function of mononuclear phagocytes. ${ }^{109110}$

The activity of both enhancing and inhibiting factors was indicated by observations on Fc receptor expression on mononuclear phagocytes in vitro. Inhibition was brought about by a heat-stable low $\mathrm{rmm}$ factor in normal serum and in supernatants of explants of human carcinomas, although it was not established whether the inhibitory factor was newly produced or merely sequestered in the tumour mass. ${ }^{73}$ Enhancement was produced by the serum from patients with untreated solid tumours. ${ }^{111}$

In relation to disordered macrophage maturation, inhibitory activity has been found in the serum of patients with breast cancer, particularly in those with node involvement. ${ }^{19}$

While these various factors of host and tumour origin may be thought of as acting specifically upon 
the mononuclear phagocytes to affect their functions, some of the observed changes in malignant disease may well be secondary to the response of lymphocytes and other cells. Lymphokines have, for example, been implicated in inducing cytotoxic activity in macrophages, ${ }^{112}$ while evidence has been found to suggest that defective monocyte chemotaxis in mycosis fungoides is secondary to a lack of essential helper lymphocyte function. ${ }^{113}$ Non-specific blocking factors which can be removed by plasma exchange $e^{114115}$ could also be implicated.

\section{Summary and conclusions}

A complex pattern of disturbed mononuclear phagocyte function is found in malignant disease; in some circumstances, functions appear to be enhanced and in others they are depressed. Enhancement of function may be interpreted as mainly a host response, and macrophage activation may be seen as an expression of an immunological reaction to the tumour, exerted through lymphokines and other host factors. Generalised functional enhancement is a prominent feature in the early stages of neoplastic growth, where there is minimal disease and the tumour is localised. Depressed function reflects subversion of macrophage activity and its presence at the local level from an early stage may be important in the establishment of the neoplasm; in the later stages of the disease, the depression of mononuclear phagocyte functions becomes generalised. The mechanisms of such subversion include soluble factors released by the tumour cells (or locally concentrated normal factors).

Interpretation is complicated by the interaction of factors, with the result that different functions of mononuclear phagocytes in malignant disease can be affected to a different degree in the same patient. Perhaps in some circumstances, mononuclear phagocytes may become "prematurely activated" and thus be prevented from ever attaining the full competence of mature tissue macrophages. Such disturbances of macrophage function are likely to be of particular significance in relation to the body's ability to eliminate tumours.

The interplay of factors of host and tumour origin upon the functions of the mononuclear phagocyte system may not only explain apparent conflicts between findings in different investigations but may also underlie the different rates of growth in different tumours. In the latter respect, the number and functional activity of macrophages gaining access to the neoplastic tissue may be of particular importance. The balance of factors may influence the overall clinical course of the disease, including the likelihood of metastasis and the susceptibility to intercurrent infection.

The importance of investigating further measures $\stackrel{\Rightarrow}{\Rightarrow}$ to restore and enhance mononuclear phagocyte func- $\stackrel{\oplus}{\rightarrow}$ tion in malignant disease is clearly indicated.

We are grateful to the Trent Regional Health $\frac{\frac{O}{\sigma}}{\frac{\pi}{2}}$ Authority for financial assistance and to Miss $\mathrm{K} \stackrel{\mathbb{D}}{\varnothing}$ Howe for typing the manuscript.

\section{References}

' Rebuck JW, Monto RW, Monaghan EA, Riddle JM. Potentialities of the lymphocyte, with an additional reference to its 0 dysfunction in Hodgkin's disease. Ann NY Acad Sci? 1958;73:8-38.

${ }^{2}$ Mahoney MJ, Leighton J. The inflammatory response to a for- $\dot{\omega}$ eign body within transplantable tumors. Cancer Res $\omega$ 1962;22:334-8.

${ }^{3}$ Alexander P. Macrophages and tumours. Schweiz Med Wochenschr 1976;106:1345-50.

4 Snyderman R, Pike MC. Pathophysiologic aspects of leukocyte $\rightarrow$ chemotaxis: identification of a specific chemotactic factor bind- $\bar{Z}$ ing site on human granulocytes and defects of macrophage function associated with neoplasia. In: Gallin JI, Quie PG, eds. $\stackrel{\bigcirc}{\supset}$ Leukocyte chemotaxis: methods, physiology, and clinical implications. New York: Raven Press, 1978:357-78.

${ }^{5}$ Rhodes J. Resistance of tumour cells to macrophages: a short $\mathbb{W}^{\infty}$ review. Cancer Immunol Immunother 1980;7:211-5.

- Keller R. Regulatory capacities of mononuclear phagocytes with particular reference to natural immunity against tumors. In: Herberman RB, ed. Natural cell-mediated immunity against tumors. New York: Academic Press, 1980:1219-69.

${ }^{7}$ Sokol RJ, Durrant TE, Hudson G. Scanning electron micros- 음 copy of skin window cells of normal subjects. J Anat $\varrho$ 1978;126:157-67.

sokol RJ, Durrant TE, Lambourne CA, Hudson G. Scanning electron microscopy of exudative macrophages in malignant lymphoma. Scand J Haematol 1979;22:129-40.

${ }^{9}$ Sokol RJ, Durrant TE, Hudson G. Skin window cellularity and macrophage changes in Hodgkin's and non-Hodgkin's lymphomas. Acta Haematol 1980;64:209-15.

${ }^{10}$ Parakkal P, Pinto J, Hanifin JM. Surface morphology of human mononuclear phagocytes during maturation and phagocytosis. $J$ Ultrastruct Res 1974;48:216-26.

"Newell DG. Scanning electron microscopy of normal and $\delta$ leukaemic human leucocytes. In: Roath S, ed. Topical reviews in haematology. Bristol: John Wright \& Sons, 1980:87-114. 윽

${ }^{12}$ Volkman A, Gowans, JL. The production of macrophages in the rat. Br J Exp Pathol 1965;46:50-61.

${ }^{13}$ Trepel F, Begemann H. On the origin of the skin window macrophages. Acta Haematol 1966;36:386-98.

14 Dent, RG, Cole P. "In vitro" monocyte maturation in squamous carcinoma of the lung. Br J Cancer 1981;43:486-95.

is Currie GA, Hedley DW. Monocytes and macrophages in malignant melanoma. I. Peripheral blood macrophage precursors. $\omega$ Br J Cancer 1977;36:1-6.

${ }^{16}$ Krishnan EC, Jewell WR. Deficiency of macrophage precursors in malignancy. Fed Proc 1979;38:1220.

${ }^{17}$ Krishnan EC, Menon CD, Krishnan L, Jewell WR. Deficiency in maturation process of macrophages in human cancer. $J$ Natl Cancer Inst 1980;65:273-6.

${ }^{18}$ Krishnan EC, Mebust WK, Weigel JW, Jewell WR. Maturation of monocytes in patients with renal cell carcinoma. Invest Urol $\mathbb{D}$ 1981;19:4-7.

19 Palmer BV, Currie G. Monocyte maturation and breast cancer. Clin Oncol 1980;6:377.

${ }^{20}$ Hedley DW, Nyholm RE, Currie GA. Monocytes and mac- 
rophages in malignant melanoma. IV. Effects of $C$ parvum on monocyte function. $B r J$ Cancer 1979;39:558-65.

${ }^{21}$ Taylor SA, Currie GA. Monocyte maturation and prognosis in primary breast cancer. $\mathrm{Br}$ Med J 1979;i:1050-1.

${ }^{22}$ Dent RG, Cole $P$. In vitro monocyte maturation as a prediction of survival in squamous cell carcinoma of the lung. Thorax 1981;36:446-51.

${ }^{23}$ Fortuny IE, Deinard A, Theologides A. The Rebuck skin window as a guide in cancer chemotherapy. Cancer Treat Rep 1976;60:903-6.

${ }^{24}$ Dizon QS, Southam CM. Abnormal cellular response to skin abrasion in cancer patients. Cancer 1963;16:1288-42.

${ }^{25}$ Goldsmith HS, Levin AG, Southam CM. A study of cellular responses in cancer patients by qualitative and quantitative Rebuck tests. Surg Forum 1965;16:102-4.

${ }^{26}$ Israël L, Samak R. A modified skin window technique as a staging tool in solid tumors. Correlation between nonspecific monocyte mobilization 'in vivo' and spread of disease. Am Assoc Cancer Res Proc 1979;20:49.

${ }^{27}$ Israël L, Samak R, Edelstein R. Defective monocyte killing in cancer patients. Lancet 1980;ii:1311.

${ }^{28}$ Samak R, Edelstein, R, Bogucki D, Samak M, Israël L. Testing the monocyte-macrophage system in human cancer. Biomedicine 1980;32:165-9.

${ }^{29}$ Samak R, Israël L, Edelstein R. Influence of tumor burden, tumor removal, immune stimulation, plasmapheresis on monocyte mobilisation in cancer patients. In: Escobar MR, Friedman $\mathrm{H}$, eds. Advances in experimental medicine and biology: macrophages and lymphocytes. New York: Plenum Press, 1980;121B:411-23.

${ }^{30}$ Normann SJ, Sorkin E. Cell-specific defect in monocyte function during tumor growth. $J$ Natl Cancer Inst 1976;57:135-40.

${ }^{31}$ Alexander P. Entry of inflammatory cells into tumors and the suppression of chronic inflammation by tumors. In: Weissmann G, Samuelsson B, Paoletti R, eds. Advances in inflammation research. New York: Raven Press, 1979;1:197204.

${ }^{32}$ Boetcher DA, Leonard EJ. Abnormal monocyte chemotactic response in cancer patients. $J$ Natl Cancer Inst 1974;52:1091-9.

${ }^{33}$ Brosman S, Hausman MS. Defective monocyte chemotactic response in genitourinary carcinoma. Urology 1974;4:129-34.

${ }^{34}$ Hausman MS, Brosman S, Snyderman R, Mickey MR, Fahey J. Defective monocyte function in patients with genitourinary carcinoma. J Natl Cancer Inst 1975;55:1047-54.

${ }^{35}$ Snyderman R, Pike MC, Meadows L, Hemstreet G, Wells S. Depression of monocyte chemotaxis by neoplasms. Clin Res 1975;23:297A.

${ }^{36}$ Snyderman R, Stahl C. Defective immune effector function in patients with neoplastic and immune deficiency diseases. In: Bellanti JA, Dayton DH, eds. The phagocytic cell in host resistance. New York: Raven Press, 1975:267-81.

${ }^{37}$ Hausman MS, Brosman SA. Abnormal monocyte function in bladder cancer patients. J Urol 1976;115:537-41.

${ }^{38}$ Rubin RH, Cosimi AB, Goetzl E. Defective human mononuclear leukocyte chemotaxis as an index of host resistance to malignant melanoma. Clin Immunol Immunopathol 1976;6:376-88.

${ }^{39}$ McVie JG, Logan EC, Kay AB. Monocyte function in cancer patients. Eur J Cancer 1977;13:351-3.

${ }^{40}$ Seitz LE, Golitz LE, Weston WL, Aeling JE, Dustin RD. Defective monocyte chemotaxis in mycosis fungoides. Arch Dermatol 1977;113:1055-7.

${ }^{41}$ Snyderman R, Seigler HF, Meadows L. Abnormalities of monocyte chemotaxis in patients with melanoma: effects of immunotherapy and tumor removal. J Natl Cancer Inst 1977;58:37-41.

42 Kjeldsberg CR, Pay GD. A qualitative and quantitative study of monocytes in patients with malignant solid tumors. Cancer 1978;41:2236-41.
${ }^{43}$ Snyderman R, Meadows L, Holder W, Wells S. Abnormal monocyte chemotaxis in patients with breast cancer: evidence for a tumor-mediated effect. J Natl Cancer Inst 1978;60:73740.

4 Snyderman R, Pike MC. Quantification of monocyte function in patients with cancer: evidence for a tumor mediated dysfunction. In: Hersh EM, Chirigos MA, Mastrangelo MJ, eds. Augmenting agents in cancer therapy. New York: Raven Press, 1981:285-93.

4s Dammacco F, Miglietta A, Ventura MT, Bonomo L. Defective monocyte chemotactic responsiveness in patients with multiple myeloma and benign monoclonal gammapathy. Clin Exp Immunol 1982:47:481-6.

${ }^{46} \mathrm{Kay}$ AB, McVie JG. Monocyte chemotaxis in bronchial carcinoma and cigarette smokers. Br J Cancer 1977;36:461-6.

${ }^{47}$ Leb L, Merritt JA. Decreased monocyte function in patients with Hodgkin's disease. Cancer 1978;41:1794-803.

4 Lukács K, Frendl G, Berényi E, Kávai M, Szabó G, Szegedi G. Monocyte chemotaxis and effect of Levamisole in Hodgkin's disease. Acta Med Acad Sci Hung 1980;37:145-50.

49 Brosman S. Alterations of monocyte chemotaxis in patients with genitourinary carcinoma. In: Crispen RG, ed. Neoplasm immunity: mechanisms. Chicago: ITR, 1976:149-56.

${ }^{\text {so }}$ Steigbigel RT, Lambert LH, Remington JS. Polymorphonuclear leukocyte, monocyte and macrophage bactericidal function in patients with Hodgkin's disease. J Lab Clin Med 1976;88:54-62.

${ }^{51}$ Kuntz BME, Kuntz RM, Albert ED. Phagocytosis of monocytes in cancer patients. $Z$ Krebsforsch 1978;91:11-7.

52 Ruco LP, Procopio A, Uccini S, Baroni CD. Increased monocyte phagocytosis in cancer patients. Eur $J$ Cancer 1980;16:1315-20.

s3 Urbanitz D, Fechner I, Gross R. Reduced monocyte phagocytosis in patients with advanced Hodgkin's disease and lymphosarcoma. Klin Wochenschr 1975;53:437-40.

${ }^{54}$ Cruchaud A, Girard J-P, Hitoglou S. The functions of human monocytes in normal subjects and in disorders associated with immune deficiency. Int Archs Allergy Appl Immun 1977;54:529-37.

${ }^{5 s}$ Estevez ME, Sen L, Bachmann AE, Paulovsky A. Defective function of peripheral blood monocytes in patients with Hodgkin's and non-Hodgkin's lymphomas. Cancer 1980;46:299 302.

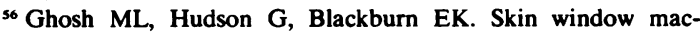
rophages in malignant lymphomas. $\mathrm{Br} J$ Haematol 1973;25:293-7.

57 Hedley DW, Currie GA. Monocytes and macrophages in malignant melanoma. III. Reduction of nitroblue tetrazolium by peripheral blood monocytes. Br J Cancer 1978;37:747-52.

ss Kitahara M, Eyre H, Hill HR. Monocyte functional and metabolic activity in malignant and inflammatory diseases. $J$ Lab Clin Med 1979;93:472-9.

s9 Salky NK, Di Luzio NR, Levin AG, Goldsmith HS. Phagocytic activity of the reticuloendothelial system in neoplastic disease. J Lab Clin Med 1967;70:393-402.

${ }^{\infty}$ Sheagren JN, Block JB, Wolff SM. Reticuloendothelial system phagocytic function in patients with Hodgkin's disease. J Clin Invest 1967;46:855-62.

${ }^{61}$ Magarey CJ, Baum M. Reticuloendothelial activity in humans with cancer. Br J Surg 1970;57:748-52.

62 Otu AA, Russell RJ, Wilkinson PC, White RG. Alterations of mononuclear phagocyte function induced by Lewis lung carcinoma in C57BL mice. Br J Cancer 1977;36:330-40.

${ }^{63}$ Nyholm RE, Currie GA. Monocytes and macrophages in malignant melanoma. II. Lysis of antibody-coated human erythrocytes as an assay of monocyte function. $\mathrm{Br} J$ Cancer $1978 ; 37: 337-44$.

ot Holm G, Bjorkholm M, Johansson B, Mellstedt H, Lindemalm C. Monocyte function in Hodgkin's disease. Clin Exp Immunol 1982;47:162-8. 
${ }^{6 s}$ Kohl S, Pickering LK, Sullivan MP, Walters DL. Impaired monocyte-macrophage cytotoxicity in patients with Hodgkin's disease. Clin Immunol Immunopathol 1980;15:577-85.

${ }^{66}$ Gill PG, Waller CA. Quantitative aspects of human monocyte function and its measurement in cancer patients. In: James $K$, McBride B, Stuart A, eds. The macrophage and cancer. Edinburgh: University of Edinburgh Medical School, 1977:37585.

${ }^{67}$ Kleinerman ES, Howser D, Young RC, et al. Defective monocyte killing in patients with malignancies and restoration of function during chemotherapy. Lancet 1980;ii:1102-5.

68 Cline MJ. Defective mononuclear phagocyte function in patients with myelomonocytic leukaemia and in some patients with lymphoma. J Clin Invest 1973;52:2185-90.

${ }^{69}$ King GW, Bain G, LoBuglio A. The effect of tuberculosis and neoplasia on human monocyte staphylocidal activity. Cell Immunol 1975;16:389-95.

${ }^{70}$ King GW, Yanes B, Hurtubise PE, Balcerzak SP, LoBuglio AF. Immune function of successfully treated lymphoma patients. $J$ Clin Invest 1976;57:1451-60.

" Rhodes J. Altered expression of human monocyte Fc receptors in malignant disease. Nature 1977;265:253-5.

${ }^{2}$ Scheinberg MA, Masuda A, Maluf JA, Mendes NF. Monocyte function in patients with solid neoplasms during immunotherapy with Corynebacterium parvum. Cancer 1978;41:1761-4.

${ }^{73}$ Rhodes J, Plowman P, Bishop M, Lipscomb D. Human macrophage function in cancer: systemic and local changes detected by an assay for $\mathrm{Fc}$ receptor expression. $\mathrm{J}$ Natl Cancer Inst 1981;66:423-9.

${ }^{74}$ Currie GA. Serum lysozyme as a marker of host resistance. II: Patients with malignant melanoma, hypernephroma or breast carcinoma. Br J Cancer 1976;33:593-9.

75 Cooper EH, Turner R, Steele L, Goligher JC. Blood muramidase activity in colorectal cancer. $B r$ Med J 1974;iii:662-4.

${ }^{76}$ Hansen NE, Karle H. Elevated plasma lysozyme in Hodgkin's disease: an indicator of increased macrophage activity? Scand J Haematol 1979;22:173-8.

" Currie GA, Eccles SA. Serum lysozyme as a marker of host resistance. I. Production by macrophages resident in rat sarcomata. Br J Cancer 1976;33:51-9.

${ }^{78}$ Ree HJ, Song JY, Leone LA, Crowley JP, Fanger H. Occurrence and patterns of muramidase containing cells in Hodgkin's disease, non-Hodgkin's lymphomas, and reactive hyperplasia. Hum Pathol 1981;12:49-59.

79 Ree HJ, Crowley JP, Leone LA. Macrophage-histiocyte lysozyme activity in relation to the clinical presentation of Hodgkin's disease: an immunohistochemical study. Cancer 1981;47:1988-93.

${ }^{80}$ Kerbel RS, Davies AJS. The possible biological significance of Fc receptors on mammalian lymphocytes and tumor cells. Cell 1974;3:105-12.

${ }^{81}$ Kerbel RS, Pross HF, Elliott EV. Origin and partial characterization of Fc receptor-bearing cells found within experimental carcinomas and sarcomas. Int J Cancer 1975;15:918-32.

${ }^{82}$ Birbeck MSC, Carter RL. Observations on the ultrastructure of two hamster lymphomas with particular reference to infiltrating macrophages. Int $J$ Cancer 1972;9:249-57.

${ }^{83}$ Haskill JS, Proctor JW, Yamamura A. Host responses within solid tumours. I. Monocytic effector cells within rat sarcomas. J Natl Cancer Inst 1975;54:387-93.

${ }^{84}$ Van Loveren H, Den Otter W. Macrophages in solid tumours. I. Immunologically specific effector cells. J Natl Cancer Inst 1974;53:1057-60.

${ }^{85}$ Spitalny GL, North RJ. Subversion of host defense mechanisms by malignant tumors; an established tumor as a privileged site for bacterial growth. J Exp Med 1977;145:1264-77.

${ }^{86}$ Russell SW, McIntosh AT. Macrophages isolated from regressing Moloney sarcomas are more cytotoxic than those released from progressing sarcomas. Nature 1977;269:69-71.
${ }^{87}$ Mansell PWA, Di Luzio NR. The in vivo destruction of human tumor by glucan activated macrophages. In: Fink MA, ed. The macrophage in neoplasia. New York: Academic Press, 1976:227-43.

s Underwood JCE. Lymphoreticular infiltration in human tumours: prognostic and biological implications: a review. $\mathrm{Br} J$ Cancer 1974;30:538-48.

${ }^{89}$ Pross HF, Kerbel RS. An assessment of intratumor phagocytic and surface marker-bearing cells in a series of autochthonous and early passaged chemically induced murine sarcomas. $J$ \& Natl Cancer Inst 1976;57:1157-67.

${ }^{90}$ Eccles SA, Alexander P. Macrophage content of tumours in $\overrightarrow{0}$ relation to metastatic spread and host immune reaction. Nature 1974;250:667-9.

${ }^{9}$ Gauci CL, Alexander P. The macrophage content of some human tumours. Cancer Lett 1975;1:29-32.

${ }^{92}$ Lauder I, Aherne W, Stewart J, Sainsbury R. Macrophage infiltration of breast tumours: a prospective study. J Clin Pathol 1977;30:563-8.

${ }^{93}$ Wood GW, Gillespie GY. Studies on the role of macrophages in $\omega$ regulation of growth and metastasis of murine chemically $\vec{\sigma}$ induced fibrosarcomas. Int J Cancer 1975;16:1022-9.

94 Currie GA, Alexander P. Spontaneous shedding of TSTA by viable sarcoma cells: its possible role in facilitating metastatic spread. Br J Cancer 1974;29:72-5.

${ }^{95}$ Ward PA, Berenberg JL. Defective regulation of inflammatory mediators in Hodgkin's disease. Supernormal levels of chemotactic-factor inactivator. $N$ Engl J Med 1974;290:7680.

${ }^{96}$ Bice DE, Gruwell D, Salvaggio J. Inhibition of macrophage migration by plasma factor(s) from patients with neoplasms and normal individuals. $J$ Reticuloendothel Soc 1976;19:2819.

${ }^{97}$ Pike MC, Snyderman R. Depression of macrophage function by a factor produced by neoplasms: a mechanism for abrogation of immune surveillance. J Immunol 1976;117:1243-9.

${ }^{98}$ Snyderman R, Pike MC. Biological activities of a macrophage chemotaxis inhibitor (MCI) produced by neoplasms. In: Quastel MR, ed. Cell biology and immunology of leukocyte function. New York: Academic Press, 1979:535-46.

${ }^{9}$ Pasternack GR, Snyderman R, Pike MC, Johnson RJ, Shin HS. Resistance of neoplasms to immunological destruction: role of a macrophage chemotaxis inhibitor. $J$ Exp Med $\overparen{O}$ 1978;148:92-102.

${ }^{100}$ Normann SJ, Sorkin E. Inhibition of macrophage chemotaxis by neoplastic and other rapidly proliferating cells 'in vitro'. Cancer Res 1977;37:705-11.

${ }^{101}$ Normann SJ, Schardt M, Sorkin E. Do tumours escape surveillance by depression of macrophage inflammation? In: James $\mathrm{K}$, McBride B. Stuart A, eds. The macrophage and cancer. Edinburgh: University of Edinburgh Medical School, 1977:247-57.

${ }^{102}$ Normann SJ. Tumor cell threshold required for suppression of macrophage inflammation. J Natl Cancer Inst 1978;60:1091- N 6.

${ }^{103}$ Normann SJ, Schardt M, Sorkin E. Cancer progression and $\mathrm{O}$ monocyte inflammatory dysfunction: relationship to tumour N excision and metastasis. Int J Cancer 1979;23:110-3.

${ }^{104}$ Rabatić S, Jurin M, Dekaris D. 'In vitro' suppression of macrophage spreading caused by supernatants of tumour, thymus 0 and lymph node cells. Folia Biol 1977;23:317-26.

${ }^{105}$ Fauve RM, Hevin M-B. Toxic effects of tumour cells on mac- $\mathscr{Q}$ rophages. In: James $\mathrm{K}$, McBride B, Stuart A, eds. The macrophage and cancer. Edinburgh: University of Edinburgh Medical School, 1977:264-70.

${ }^{106}$ Cantarow WD, Cheung HT, Sundharadas G. Modulation of spreading, adhesion and migration of peritoneal macrophages $\mathbb{C}$ by a low molecular weight factor extracted from mouse 2 tumors. J Reticuloendothel Soc 1978;24:657-66.

${ }^{107}$ Ramarao GVSV, Tompkins WAF. Inhibition of macrophage 
phagocytosis by a human colon tumor cell factor. $J$ Reticuloendothel Soc 1978;23:373-82.

${ }_{108}$ Saito H, Tomioka H. Suppressive factor against macrophage phagocytosis produced by cultured sarcoma-180 cells. Gann 1979;70:671-5.

109 North RJ, Kirstein DP, Tuttle RL. Subversion of host defense mechanisms by murine tumors. I. A circulating factor that suppresses macrophage-mediated resistance to infection. $J$ Exp Med 1976;143:559-73.

10 North RJ, Kirstein DP, Tuttle RL. Subversion of host defense mechanisms by murine tumors. II. Counter-influence of concomitant antitumor immunity. $J$ Exp Med 1976;143:574-84.

"' Rhodes J, Bishop M, Benfield J. Tumor surveillance: how tumors may resist macrophage-mediated host defense. Science 1979;203:179-82.

112 Fidler IJ. Activation of mouse macrophages by syngeneic, allogeneic, or xenogeneic lymphocyte supernatants. J Natl Cancer Inst 1975;55:1159-63.
${ }^{113}$ Norris DA, Perez RE, Golitz LE, Seitz LE, Weston WL. Defective monocyte chemotaxis in mycosis fungoides: lack of essential helper lymphocytes. Cancer 1979;44:124-30.

114 Israël L, Edelstein R, Mannoni P, Radot E, Greenspan EM. Plasmapheresis in patients with disseminated cancer: clinical results and correlation with changes in serum protein. The concept of 'nonspecific blocking factors'. Cancer 1977;40:3146-54.

115 Israël L, Edelstein R. 'In vivo' and 'in vitro' studies on nonspecific blocking factors of host origin in cancer patients. Role of plasma exchange as an immunotherapeutic modality. Isr $J$ Med Sci 1978;14:105-30.

Requests for reprints to: Dr RJ Sokol, University Department of Haematology, Royal Hallamshire Hospital, Sheffield, S10 2JF, England. 